\title{
Vivencia del Maestro Sanín Cano
}

$\mathbf{H}^{\prime}$ ABLARÁN otros, con mayor autoridad sin duda, de la múltiple, recia y duradera labor de don Baldomero Sanín Cano, en el homenaje tan generoso como justo que le rinde la Revista IBEroAMERICANA y en el que he sido tan gentilmente invitado a tomar parte. Aceptando con alegría el ofrecimiento, procuraré, trataré por mi parte de decir algo, según me sea posible decirlo, acerca de la personalidad misma del maestro, tal como me fué dado conocer y tratar a ésté durante semanas que hubieron de ser para mí, por lo deleitosas e instructivas, demasiado fugaces.

Fuéme dado, en efecto, conocer en persona a Sanín Cano -a quien conociera ya antes, de nombre y por sus obras- durante el transcurso de la VIII Conferencia Panamericana, en Lima, la ciudad linda y graciosa como una andaluza americana de excelente cepa, dentro de su tradicional donaire peruanísimo. Formábamos parte Sanín Cano y yo de nuestras delegaciones respectivas a aquella memorable conferencia. Envueltos ambos en la ola mayoritaria de estadistas, economistas, políticos, que llenaba el gran Hotel Bolívar, donde casi todos, llenándole hasta los topes, residiamos, y asistiendo a las sesiones de la conferencia misma, apenas pude, tres o cuatro veces, charlar con don Baldomero, en relativas pausas no muy largas. Almorzamos por primera vez juntos, y fuera de todo protocolo, en el hermoso Club de la Unión, en los postreros días de la reunión hemisférica. $\mathrm{Y}$ nos hicimos desde entonces amigos para el resto de nuestros días mortales. Enterámonos mutuamente de que íbamos los dos, apenas terminada la Conferencia de Lima, y en representación asimismo de nuestros países, a otra asamblea, de proporciones y propósitos más reducidos y especializados; pero por lo mismo, más en consonancia con nuestras inclinaciones y con la 
vocación - llamada vital - de nuestro destino: la Primera Conferencia de Cooperación Intelectual celebrada en otra gran ciudad de nuestra América, acogedora y cordial, por lo demás, como pocas, y de ilustre prosapia literaria: Santiago de Chile.

Cosa de una semana después, en el Hotel Crillon de Santiago, donde residíamos mi esposa y yo, así como la mayor parte de los demás delegados y sus esposas respectivas, nos reunimos de nuevo con nuestro ya viejo amigo - que no se cuenta a veces la amistad por los años de su duración, sino antes por la hondura y sanidad de sus raíces de estima y afecto, que son por su naturaleza atemporales. Juntos estábamos casi de la mañana a la noche, en el hotel mismo, en los numerosos actos sociales con que nos obsequiaba el gobierno recién inaugurado del presidente don Pedro Aguirre Cerda y la distinguida sociedad de Santiago así como durante las interesantísimas sesiones de la conferencia, presidida, a su vez, por otro ilustre y buen amigo: don Juvenal Hernández, en la Universidad de Chile, de la cual era él Rector a la sazón. Tomaban parte en aquélla numerosas personalidades, todas eminentes, de nuestro hemisferio y algunas europeas. Don Baldomero fué tácita y unánimemente reconocido como el patriarca americano de la conferencia.

Durante el transcurso de la cual, según apunté antes, tuve ocasión, para mí bienvenida, de proseguir con el maestro Sanín Cano, $\mathrm{y}$ con sosiego y espacio mayores y tiempo más propicio y prolongado la conversación que con él comenzara en Lima. La conferencia misma era, en vez de agotadora, estimulante. Las sesiones eran agradables y fecundas. Los temas tratados nos apasionaban a todos. E1 tono fué de verdadera e íntima cordialidad.

$\mathrm{Y}$ el patriarca de la conferencia, repitámoslo, fué el maestro Sanín Cano. Cada uno de nosotros supo, al tratarle, por qué sus compatriotas todos le saludan con título tan alto. Este gran don Baldomero sin barbas capriles como las de don Ramón del ValleInclán ( $\sin$ la mordacidad valleinclanesca tampoco, a veces ácida y maldiciente) posee una sabiduría vital sonriente y un humorismo antioqueño de la mejor agua, tan serenos y benévolos ambos, como corresponde a un maestro consumado de la mente y del vivir humanos. Su figura alta y fuerte es la de un hombre situado entre la quinta y la sexta década de su existencia. Parece atesorar en su testa venerable y a menudo risueña un archivo inagotable de saber 
de los libros y del mundo, de los hombres y países diversos que conoció en su esencialidad y en sus detalles cotidianos, reveladores del alma y carácter de países y hombres. $\mathrm{Y}$ ama a su patria ilustre de democracia y de cultura y su provincia, como él sana y recia, con amor cuya profundidad se recata en un viril pudor que lo revela $y$ trasciende.

Sencillo y verdadero, como un gigante sin complejos, y como un sage que superó la vida sin mostrarlo, se me apareció siempre don Baldomero Sanín Cano, en los días, demasiado cortos por lo cordiales y fértiles, de la Primera Conferencia de Cooperación Intelectual. Por sobre todos mis recuerdos de ella, y del país fraterno donde ella se celebró, se eleva la figura amada del insigne delegado de Colombia. Tiempo ha que deseaba expresarlo. De ahí mi gratitud a mis distinguidos amigos y colegas: el director de la Revista Iberoamericana, señor Julio Jiménez Rueda y su redactor, señor Manuel Pedro González, quienes me han ofrecido la más propicia ocasión de realizar, siquiera a vuela pluma a causa de la premura a que otrós quehaceres del momento me obligan, mi anhelo y cumplir, siquiera haya de ser de suerte somera, el deber de unir este mi tributo al homenaje de alta justicia de la gran revista.

Abrigo la esperanza fundada de que hayamos de tener nueva oportunidad de renovar tal homenaje al Néstor de las letras americanas. Entretanto, desde esta tierra también hermana de la mía, le envío mi saludo filial de admiración y afecto:

¡Maestro, salud!

LUIS Rodríguez-ÉmbIL, Caracas, Venezuela. 
